UDC 636.082: 22 / 28.034.061

(C) 2020

\title{
Influence of genotypical and paratypical factors on the productivity of dairy cattle
}

\author{
Bashchenko M. ${ }^{1}$, Boyko O. ${ }^{2}$, Gonchar O. ${ }^{3}$, Sotnichenko Yu. ${ }^{4}$, Tkach Ye. ${ }^{5}$ \\ Cherkasy Experimental Station of Bioresources of NAAS, 76 Pasterivska Str., Cherkasy, 18036, Ukraine \\ e-mail: ${ }^{1}$ bioresurs.ck@ukr.net, ${ }^{2} a l e k s b o y 18 @ m e t a . u a,{ }^{3}$ ofgonchar@gmail.com, ${ }^{4}$ sotnichenko.yulya@ \\ gmail.com, ${ }^{5}$ Lerikggguter @gmail.com
}

Goal. To study the effect of the genotype of the parents and of parameters of microclimate on the productivity of dairy cattle. Methods. Analysis of experimental studies on the application of effective methods of selection, the study of the environment, assessment of productive qualities of animals for growing in various types of buildings. Results. The formation of the genetic potential of dairy breeds was made according to the breeding value of pedigree bulls. The share of influence of the bull based on «hope» is $16.4-34.5 \%$, and on the fat content in the milk $-15.3-20.1 \%(P<0.001)$. One of the many factors influencing the productivity of agricultural animals is the parameter of the microclimate in the building where they are kept. In the cold period of the year the most problematic in terms of comfort there are periods of prolonged cold. In loose housing of cows, the decrease of milk yield because of frosts reached $1.5 \mathrm{~kg}$ per day. The strength of the influence of the temperature and the velocity of the air in the general phenotypical variability in the level of milk yield and yield of milk fat over the lactation into account respectively made $33.6(P<0.001), 29.4(P<0.05), 35.3(P<0.001)$, and 28.3\% $(P<0.05)$ respectively. It is established that to improve the profitability of livestock breeding the microclimate in the building requires significant improvements in the winter-summer period of the year at the natural ventilation system. Conclusions. Quantitative and qualitative indicators of milk productivity of cows of native breeds are determined by breeding value and linear membership of bulls, used for the reproduction of breeding stock. A favorable climate should be considered as an important factor of the realization of genetic potentialities of dairy cattle at pure breeding.

Key words: breeding, animals breeding value, parameters of the microclimate, effectiveness. DOI: https://doi.org/10.31073/agrovisnyk202003-08

Among the factors that influence the change of the domestic gene pool, the use of the best world breed gene pool is of great importance. It is purebred animals that make it possible to use highly efficient technologies, as they show the standard of the required characteristics and their stability. The smaller the coefficient of variation of a particular trait, the higher the degree of homo- and taut zygote, the greater the breeding value of the breed [1-3].

The objective identification of the factors that determine the level of milk productivity is an in-depth basis for choosing a breeding method aimed at hereditary improvement of physiological features that limit the performance of the animals being evaluated $[4,5]$.

It is known that for most farm animals the thermo neutral zone is quite wide. However, for highly productive herds the creation of optimal microclimate is very important, since intensive animal exploitation requires the maximum voltage of all systems of the body, which cannot but affect the level of their resistance and productivity [6-8]. Studies of scientists and observations of technologists indicate that in many rooms, the microclimate does not always meet the zootechnic requirements, especially in terms of temperature and relative humidity [9]. According to G.N. Samarin [10], deviation of the microclimate parameters from the set optimal limits can lead to a decrease in milk yield, increase in live weight, increase of young animals' waste, decrease of animal resistance to diseases, costs of additional feed, short-term operation of equipment and premises and negative impact on the staff.

Purpose of research. To study the influence of parental genotype and microclimate parameters on dairy cattle productivity.

Materials and methods of research. The researches were carried out in the breeding farms of Cherkasy region PJSC "NGO" Progress "and LLC" RVD-Agro "on cows of Ukrainian red and black-rippled dairy breeds in different types of premises: lightweight type (frame building), of reinforced concrete three-layer panels of continuous section. Compatible with rooftop brick roofs on farms with natural exhaust ventilation system. The studies were performed using microclimate assessment techniques [11]. Materials on space-planning decisions of premises were collected by the methods of description and measurement (Leica Disto D210 rangefinder). The power of influence $\left(\eta_{x}{ }^{2}\right)$ of various genotypic and paratypical factors for basic economic usefulness were studied by the method of one-factor dispersion complex due to the ratio of factorial dispersion to the total [12]. Research 
materials were biometrically processed using software Statistica 6.0.

Research results. Formation of the genetic potential of dairy breeds is to some extent determined by the value of the brooders used to reproduce the uterine herd (Table 1.).

1. The effect of genotype factors on the performance of dairy cows

\begin{tabular}{|c|c|c|c|c|c|c|c|c|}
\hline \multirow{3}{*}{ Impact factor } & \multicolumn{4}{|c|}{ The first lactation $(n=251)$} & \multicolumn{4}{|c|}{ Higher lactation $(n=98)$} \\
\hline & \multicolumn{2}{|c|}{ milk yield } & \multicolumn{2}{|c|}{$\%$ fat } & \multicolumn{2}{|c|}{ milk yield } & \multicolumn{2}{|c|}{$\%$ fat } \\
\hline & $\eta_{\mathrm{x}}^{2}$ & $\mathrm{~F}$ & $\eta_{\mathrm{x}}^{2}$ & $\mathrm{~F}$ & $\eta_{\mathrm{x}}^{2}$ & $\mathrm{~F}$ & $\eta_{\mathrm{x}}^{2}$ & $\mathrm{~F}$ \\
\hline \multicolumn{9}{|c|}{ Ukrainian black-and-white dairy breed } \\
\hline $\begin{array}{l}\text { The genotype } \\
\text { of the cow }\end{array}$ & $0,038^{* * *}$ & 4,81 & 0,018 & 2,17 & $0,044^{*}$ & 2,97 & $0,065^{*}$ & 2,92 \\
\hline Father's PC & $0,165^{\star * *}$ & 5,01 & $0,189^{* * *}$ & 4,59 & $0,164^{* *}$ & 3,17 & $0,188^{* *}$ & 2,74 \\
\hline Father's line & $0,104^{* *}$ & 3,20 & $0,144^{* * *}$ & 16,6 & $0,108^{* * *}$ & 7,87 & $0,137^{* *}$ & 3,89 \\
\hline \multicolumn{9}{|c|}{ Ukrainian red-and-white milk breed } \\
\hline $\begin{array}{l}\text { The genotype } \\
\text { of the cow }\end{array}$ & 0,029 & 1,27 & 0,032 & 1,34 & 0,008 & 0,23 & 0,059 & 1,3 \\
\hline Father's PC & $0,246^{* *}$ & 2,00 & $0,153^{* * *}$ & 0,95 & $0,345^{\star * *}$ & $0,341^{* * *}$ & $0,201^{*}$ & 0,3 \\
\hline Father's line & $0,134^{* * *}$ & 3,39 & $0,149^{*}$ & 1,94 & $0,102^{* * *}$ & 4,27 & $0,141^{*}$ & 0,4 \\
\hline
\end{tabular}

Remark: * $\mathrm{P}<0,5 ;{ }^{* *}-\mathrm{P}<0,01 ;{ }^{* * *}-\mathrm{P}<0,001$.

The influence of the father in the overall variability of milk yield and fat content of cows of Ukrainian blackand-white milk dairy breed for the accounted lactations was accordingly $16.5-18.9 \%$ and $16,4-18.8 \%$ with confidence within $\mathrm{P}<0.01-0.001$. Among the cows of Ukrainian red-and-white milk dairy breed, the share of the influence of the breeding value of the father in the total phenotypic variability of milk yield and fat content, respectively, was at the first lactation $24.6-15.3 \%$ and $34.5-20.1 \%$ with confidence within $P<0.01-0.001$.

The influence on the hope and fat content of the father's lineage milk was by the first and higher lactations of the Ukrainian black-and-white milk breed, respectively $10.4-14.4 \%$ and $10.8-13.7 \%$. The influence of the father's line on similar indicators of milk yield and fat content among cows of Ukrainian red-and-white milk dairy breed, which accounts for the first lactation respectively, was revealed at almost the same level $13.4-14.9 \%$ and beyond $-10.2-14.1 \%$. Quantitative and qualitative indicators of dairy productivity depend to a large extent on the breeding value and linear affiliation of the boogie-sucker.

One of the many factors influencing the formation of farm animals is undoubtedly the microclimate parameters of the premises in which they are (Table 2).

2. Correlation coefficients between microclimate characteristics and average daily cow productivity

\begin{tabular}{|c|c|c|c|c|}
\hline \multirow[b]{2}{*}{ Indicator } & \multicolumn{2}{|c|}{ Cold period } & \multicolumn{2}{|c|}{ The coldest period } \\
\hline & $\begin{array}{c}\text { milk } \\
\text { yield. } \mathrm{kg}^{* \star *}\end{array}$ & $\begin{array}{l}\text { contents } \\
\text { fat, } \%\end{array}$ & $\begin{array}{c}\text { milk } \\
\text { yield. } \mathrm{kg}^{* * *}\end{array}$ & $\begin{array}{l}\text { contents } \\
\text { fat, } \%\end{array}$ \\
\hline Milk yield. $\mathrm{kg}^{* * *}$ & 1 & $-0,736^{\star *}$ & 1 & $-0,826^{*}$ \\
\hline Fat content in milk, \% & $-0,736^{\star *}$ & 1 & $-0,826^{* *}$ & 1 \\
\hline Average air temperature, ${ }^{\circ} \mathrm{C}$ & $0,250^{\star *}$ & 0,017 & $0,786^{* *}$ & $-0,815^{\star \star}$ \\
\hline The minimum air temperature, ${ }^{\circ} \mathrm{C}$ & $0,170^{*}$ & 0,054 & $0,879^{* *}$ & $-0,750^{* *}$ \\
\hline Maximum air temperature, ${ }^{\circ} \mathrm{C}$ & $0,276^{\star \star}$ & 0,003 & $0,905^{\star *}$ & $-0,629^{* *}$ \\
\hline Atmospheric pressure, $\mathrm{mm} . \mathrm{Hg}$ & $-0,216^{\star *}$ & 0,114 & $-0,620^{\star *}$ & $0,591^{\text {** }}$ \\
\hline Relative humidity, $\%$ & $-0,378^{\star *}$ & $0,308^{* *}$ & $0,792^{* *}$ & $-0,743^{* *}$ \\
\hline Air velocity, $\mathrm{m} / \mathrm{s}$ & $-0,056$ & 0,057 & $-0,443^{*}$ & $0,456^{\star *}$ \\
\hline
\end{tabular}

Remark: ${ }^{*}$ the probability of the correlation coefficient $\mathrm{P}<0,05^{* *}$ - the probability of the correlation coefficient $\mathrm{P}<0,01 ;{ }^{* * *}-$ average daily milking per cow, adjusted for the average herd of lactation. 
It is established that during the cold period of the year (from October to April, lasting 195 days), when the average daily ambient air temperature ranged from $+10^{\circ} \mathrm{C}$ to $-26^{\circ} \mathrm{C}$, the most difficult, from the point of view of comfort, for cattle are periods of prolonged frost. In modern types of rooms, the climate conditions are far from comfortable enough: the air temperature is $-12-15^{\circ} \mathrm{C}$, the surface temperature of the litter in some places decreased to $-11,9^{\circ} \mathrm{C}$. In addition, due to the accumulation of animals in the premises, the $\mathrm{CO}_{2}$ concentration at some points reached $0.89 \%$, which is 3.6 times the maximum permissible concentration (MPC), but the $\mathrm{NH}_{3}$ and $\mathrm{H}_{2} \mathrm{~S}$ content were at levels well below the MPC.

During the cold period of the year, when the cows were kept unattended, the correlation coefficients between the average daily milk yield per cow and the nighttime air temperature were $r=0.250(P<0.01)$; between average daily milking per cow and nighttime atmospheric pressure $r=-0.216(P<0.01)$. It should be noted that when considering the same dependence, during the period of time (42 days - from January 11 to February 22), when the coldest winter period occurred, significantly higher degrees of association of milking with the above two indicators were established - respectively $r=0.786$ and $r=-0.620(P<0.01)$. At the same time, the decrease in daily milk yields due to frosts reached $1.5 \mathrm{~kg}$ per day.

Different genotypes are not always equally affected by the environment. The interaction of the genotype of dairy cattle and the environment has been studied at the Langhill Research Centers in Scotland and Moorepark in Ireland. Particular attention was paid to the microclimate parameters for high-yielding animals. It is established that in cows with high genetic potential for milking at optimal humidity and temperature conditions metabolism processes increase, and, as a consequence, milk production [13]. This conclusion of foreign scientists is consistent with the conclusions obtained from the results of these studies.

The obtained coefficients of force of influence of paratype factors, among which year and season of birth and calving, convincingly testify only high and reliable influence of factor of year on dairy productivity of cows (Table 3). The mere factor of the year of birth of the calf cannot directly affect its future dairy productivity, but indirectly the quantitative traits depend on the conditions created in a particular year for the rearing of the young, as well as the conditions of feeding and keeping the first-born cows in a particular year of their calving. This is clearly confirmed by the indicators of the force of influence of years of birth and first calving, the proportion of which in the total variability of milk yield and milk fat output of the first lactation, respectively, was 26.8-41.0 and 29,9$46.1 \%$ with high Fisher credibility criteria $(P<0.001)$.

\section{The effect of paratype factors on the performance of dairy cows}

\begin{tabular}{|l|c|c|c|c|c|c|}
\hline \multirow{2}{*}{ Indicator } & \multirow{2}{*}{$\begin{array}{c}\text { Number } \\
\text { of } \\
\text { gradations }\end{array}$} & $\mathrm{n}$ & \multicolumn{2}{|c|}{ Milk yield, kg } & \multicolumn{2}{c|}{ Milk fat, $\mathrm{kg}$} \\
\cline { 5 - 6 } & 17 & 251 & $\eta_{\mathrm{x}}^{2}$ & $\mathrm{~F}$ & $\eta_{\mathrm{x}}^{2}$ & $\mathrm{~F}$ \\
\hline Year of birth & 24 & 251 & 0,067 & 16,08 & 0,299 & 18,46 \\
\hline Season birth & 17 & 251 & 0,410 & 27,46 & 0,077 & 14,32 \\
\hline Year of first calving & 24 & 251 & 0,008 & 1,89 & 0,461 & 32,75 \\
\hline The first calving season & 14 & 251 & 0,051 & 1,99 & 0,055 & 1,56 \\
\hline Atmospheric pressure & 19 & 251 & 0,336 & 1,86 & 0,353 & 1,07 \\
\hline Temperature mode & 14 & 251 & 0,059 & 2,87 & 0,056 & 2,74 \\
\hline Humidity & 14 & 251 & 0,294 & 1,65 & 0,283 & 1,58 \\
\hline Air velocity & & & &
\end{tabular}

Equally important is the study of the level of influence on the milk yield and milk fat content of the microclimate parameters: temperature and humidity, atmospheric pressure and air velocity. According to our research, the influence of temperature and air velocity in the total phenotypic variability of milk yield and milk fat yield for the accounted lactation were respectively $33.6(P<0.001)-29.4(P<0.05)$ and $35.3(P<0.001)-28.3 \%(P<0.05)$, the obtained high coefficients are confirmed by the Fisher criterion. Analogous results were obtained from Mellado M. and co-authors who indicate a negative temperature effect on maximum productivity of Holstein cows [14]. Hill DL, Wall E. found that wind speed, day length, and temperature have a significant impact on milk reliability and composition [15]. According to the variance analysis, the influence of humidity regime and atmospheric pressure was not high enough and was estimated according to the indicators 5,9-5,1 and 5,6-5,5\%.

\section{Conclusions}

Quantitative and qualitative indices of dairy productivity of cows of domestic breeds are determined by the breeding value and lineage of the booger-brooders used for reproduction of uterine livestock. The share of the influence of the captive on the sign of "yield" is 16.4-34.5\%, and the fat content of milk-15.3-20.1\% $(P<0.001$.).

The force of the influence of temperature and air velocity in the overall phenotypic variability of milk yield and milk fat yield for the accounted lactation, respectively, was 33,6 $(P<0.001)-29.4(P<0.05)$ and $35.3(P<0.001)-$ $28.3 \%(P<0.05)$. Therefore, a favorable microclimate must be considered as an important factor in the realization of the genetic inclinations of dairy cattle for purebred breeding. 


\section{References}

1. Bliznychenko, O. (2007). Henetychni osnovy porodoutvorennia [Genetic basis of rock formation]. Breeding and genetics of animals, 41, 17-26. [In Ukrainian].

2. Kramarenko, S., Kuzmichova, N. I., \& Kramarenko, O. S. (2018). Analiz vzaiemodii «henotyp $\times$ seredovyshche» na molochnu produktyvnist koriv [Analysis of the interaction of genotype $\times$ environment on dairy productivity of cows]. Scientific Bulletin of S. S. Gzitsky, 20(89), 27-34. doi: 10.32718/nvlvet8905. [In Ukrainian].

3. Haile-Mariam, M., Carrick, M. J., \& Goddard, M. E. (2008). Genotype by environment interaction for fertility, survival, and milk production traits in Australian dairy cattle. Journal of Dairy Science, 91(12), 4840-4853. doi: 10.3168/jds.2008-1084.

4. Gonchar, O. F., Sotnichenko, Yu. M., Tkach, E. F., \& Lyashenko, A. O. (2011). Udoskonalennia systemy utrymannia khudoby na molochnykh kompleksakh v Cherkaskii oblasti: metodychni rekomendatsii ChDSB IRHT NAAN [Improvement of the system of keeping cattle at dairy complexes in Cherkasy region]. Guidelines for the BSDP of the IRGT NAAS. [In Ukrainian].

5. Jonas, E. M., Atasever, S., Graff, M., \& Erdem, H. (2016). Non-genetic factors affecting milk yield, composition and somatic cell count in Hungarian Holstein cows. Kafkas Üniversitesi Veteriner Fakültesi Dergisi, 22(3), 361-366. doi: 10.9775/kvfd.2015.14672.

6. Šimková, A. et al. (2016). The Effect of Stable Microclimate on Milk Production of Dairy Cattle. Scientific Papers: Animal Science and Biotechnologies, 49(1), 186-189. 46.

7. Summer, A. et al. (2019). Impact of heat stress on milk and meat production. Animal Frontiers, 9(1), 39-

8. ElBoshra, M. E., Ali, T. E., \& Hassabo, A. A. (2016). Genetic and environmental factors affecting 305-day ma-ture equivalent milk yield of Holstein Friesian cows in the United Arab Emirates. Journal of Agricultural and Marine Sciences, 21(1), 2-7. doi: 10.24200/ jams.vol21iss0pp1-6.

9. Tkach, E. (2013). Vliyanie parametrov mikroklimata pomeshcheniy razlichnogo tipa na produktivnost korov. Nauchnoe obespechenie innovatsionnogo razvitiya zhivotnovodstva: cb. nauchnykh trudov po mat. [The influence of the microclimate of various types of premises on the productivity of cows. Scientific support for the innovative development of animal husbandry: Sat. scientific papers on the mat.]. Mezhdunar. nauchno-prakt. konf. (24-25 oktyabrya 2013 g.) [Int. Scientific and practical. Conferences (October 24-25, 2013)]. Zhodino. RUE "Scientific and Practical Center of the National Academy of Sciences for Livestock". (pp. 472-474). [In Russian].

10. Samarin, G. N. (2009). Energosberegayushchaya tekhnologiya formirovaniya mikroklimata $v$ zhivotnovodcheskikh pomeshcheniyakh [Energysaving technology for the formation of microclimate in livestock buildings]. Moscow. [In Russian].

11. Voloshchuk, V. M., Nebilitsa, M. S., Vashchenko, O. V., \& Mazanko, M. O. (2016). Innovatsiinyi sposib monitorynhu pokaznykiv mikroklimatu tvarynnytskykh prymishchen: metod. rekomendatsii [Guidelines. An innovative way of monitoring livestock microclimate indices]. Cherkasy: Cherkasy Biological Resources Research Station of NAAS. [In Ukrainian].

12. Ibatulin, I. I., \& Zhukorsky, O. M. (eds.) (2017). Metodolohiia ta orhanizatsiia naukovykh doslidzhen u tvarynnytstvi [Methodology and organization of scientific research in animal husbandry]. Handbook, Kiev: Agrarian Science. [In Ukrainian].

13. Mellado, M., Antonio-Chirino, E., Meza-Herrera, C., Veliz, F.G., Arevalo, J. R., Mellado, J., \& de Santiago, A. (2011). Effect of lactation number, year, and season of initiation of lactation on milk yield of cows hormonally induced into lactation and treated with recombinant bovine somatotropin. J Dairy Sci, 94, 4524-4530, doi: 10.3168/jds.2011-4152.

14. Hill, D. L., \& Wall, E. (2015). Dairy cattle in a temperate climate: the effects of weather on milk yield and composition depend on management. J. Dairy Sci. 9(1), 138-149. doi: 10.1017/S1751731114002456

15. Beerda, B., Ouweltjes, W., Šebek, L. B., Windig, J. J., \& Veerkamp, R. (2007). Effects of Genotype by Environment Interactions on Milk Yield, Energy Balance, and Protein Balance. Journal of Dairy Science, 90(1), 219-228. doi: 10.3168/jds.S0022-0302(07)72623-1. 